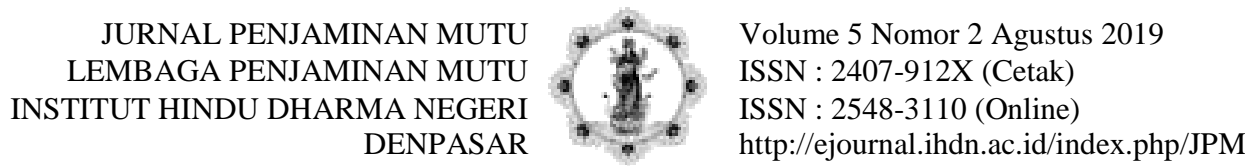

\title{
CYBER BULLYING PREVENTION AND HANDLING THROUGH HINDU FAMILY EDUCATION
}

\author{
Oleh \\ I Ketut Sudarsana ${ }^{*}$, I Wayan Lali Yogantara, Ni Wayan Ekawati \\ Institut Hindu Dharma Negeri Denpasar, Bali, Indonesia \\ *iketutsudarsana@ihdn.ac.id
}

diterima 13 Juni 2019, direvisi 20 Juli 2019, diterbitkan 31 Agustus 2019

\begin{abstract}
Technological developments have positive and negative impact on teenagers in particular. The most common negative impact of technology is cyber bullying. In globalization era and technological development, nowadays computer can produce multifunctional internet. All good and evil behavior can be done on social media. Before the development of the internet, cyber bullying actor committed their crimes in the real world. Cyber bullying actor can hurt and make many individuals uncomfortable in their lives. The crime is called bullying. Nowadays, the bullying can be done through any other media indirectly such as social media and it called cyber bullying. According to the Hinduja and Patching Cyber-Bullying researcher, the behavior is described as intentional action by sending electronic text (e-mail), or recording images that are usually uploaded to social media (youtube). The contents uploaded such as mocking, harassing, threatening, harassing, or insulting.
\end{abstract}

\section{Keywords: Cyber Bullying; Handling; Hindu Family Education}

\section{INTRODUCTION}

The development of communication and information technology is currently taking a role in changing the mindset and attitudes of students. On the one hand, the internet has a positive influence on teenagers because they can build social identities related to anxiety. Students as original digital are presented with a wide choice of the latest communication technology, but they still lack ethical verification while communicating using the internet. In Indonesia, digital literacy still requires technical competence using the internet. While based on individual competencies compiled by the European Commission (2009) to measure one's media literacy level, more than three comments should be released, namely technical ability, critical understanding, and communication and support abilities. 
Cyberbullying is an event when a child or teenager is ridiculed, insulted, intimidated, or humiliated by children or teenagers through the internet, digital technology or cell phones.

Cyberbullying is considered valid if it is approved and accepted under 18 years and has been approved as an adult. If one of the parties involved (or the party) has participated over 18 years, then the case will be categorized as cyberspace or cyberspace prosecution (or often called cyber harassment).

The motivations of cyberbullying benefits also vary. There is a need for reasons of anger and want revenge, frustration, or want to seek attention, or some are just asking for fun. Not infrequently the motivation is rarely joking. Perpetrators or acts of cyberbullying are certainly not worth emulating.

Children or adolescents who commit cyberbullying to participation do not support what is bad. The person he taunts can be disappointed, sad, depressed, and can withdraw from his environment because he has no self-confidence. This is very detrimental and makes other people get negative effects from cyberbullying. For this reason, an important role is important in the success of cyberbullying.

Cyberbullying can affect mental health. The perpetrators of this bullying try to get inside their heads and make the victims deserve valuable and miserable. Victims are also always afraid of what will happen next. This can cause some serious damage to overall health. Victims of cyberbullying are generally physical and mental health problems.

Physical Facts: Eating loss, difficulty sleeping or sleep disturbance, complaints of skin problems, digestion and palpitations.

Psychological Symptoms: Restlessness, depression, Fatigue, decreased self-esteem, difficulty concentrating, depressed, broken self, irritable, to self-destruction (Dinkes, 2015).

\section{Cyberbullying phenomenon will continue} to undermine the mental health of adolescents, so it needs the attention of many parties in overcoming this problem. It takes the role of health and education stakeholders as well as being supported by parents to be able to participate in supporting this problem as time goes on to approach teenagers.

Programs that are needed to increase understanding of adolescents at school or campus, educators and parents in order to overcome cyberbullying and long-term improvement that can damage the health and mental health of children \& adolescents.

Cyber bullying or harassment through technological media conducted by students is one of the forms of trend crime that has spread recently. Implicitly, cyber bullying can spread by using technological media such as SMS, e-mail, social media that has the main purpose to bully by harass, humiliate and intimidate someone. It has vary forms, for example spreading hoax news or issues, posting embarrassing photos, sexual harassment, or threat to actions that lead to exploitation (Furgon, 2010). So that many education observers over the world sometimes blame and manipulate on the basis of these problems. Some of them believe that the main factor is the wrong parenting parents at home, the degradation education system in schools, the technology development trend spread without any moral ability or good human resources preparation, the most extreme factor is the existence of religion as an excuse, and other things (Saksono, 2008). So that way, looking for solution of the problems such as cyber bullying is a wise nature today.

\section{DISCUSSION \\ 2.1 Definition and Causes of Cyber Bullying}

Cyber bullying is all forms of violence that experienced by children or adolescents and carried out by their peers through the cyber world or the internet. Cyber bullying is an incident when a child or teenager is ridiculed, humiliated, intimidated, or humiliated by another child or teenager through internet media, digital technology or cell 
phone. Cyber bullying is considered valid if the cyber actor and victim are under 18 years old and legally not considered as adult. If one of the parties involved (or both) is over 18 years old, then the case will be categorize as cybercrime or cyber stalking and often also called cyber harassment (Priyatna, 2005).

The forms and methods of cyber bullying action are very diverse. It can be a threat message by e-mail, uploading embarrass photos of the victim, create a website to spread hoax content to make the victim shy and mocking the victim, accessing other people's social networking accounts without permission to intimidate victims and make trouble. The Motivation of the cybercrime actors is also diverse. Some of them do it because they are angry and want revenge, frustrated, want to seek attention and some even make it just to entertain their selves during their spare time. Sometimes the motivation of cyber bullying actor just wants to joke to the victim (Samba, 2013). We can conclude that minimum understanding moral education in technology happen to cyber bullying actor. According to Furgon states that, children or adolescents commit cyber bullying usually choose to disturb other children who are considered weaker, do not like to fight and cannot make a good self-defense (Furgon, 2010). The cyber bullying actors are usually children who want to be powerful or like to dominate. These children are usually more powerful, have higher social status and are more popular among their friends while the victims are usually children or teenagers who are often ridiculed and humiliated because of their appearance, skin color, their family, or the way they behave in school. Contrarily, the victim of cyber bullying is also could be a child who is popular, smart, and prominent in school so that make other friends envy and do the cyber bullying.
This phenomenon shows the principle Hinduism value education is in line with it, that a child who does not get a good education will naturally lead to the properties of Asuri Sampad (animalistic nature) (Titib, 2006). The animalistic nature of a child will manifest in every move of his life especially in terms of using technology tools that are increasingly modern and sophisticated. So nothing limitation in terms of using technology, then they will arbitrarily commit a crime without guilt especially abuse issues such as cyber bullying.

\subsection{Prevention of Cyber Bullying through Family Education}

The right strategy must be based on the right root of the problem. So to be able to minimize cyber bullying we need to know, what factors influence the perpetrators can do cyber bullying?

The involvement of perpetrators in bullying is related to family predictors. Furthermore the reason for cyber bullying that occurs among teenagers is that one of them is due to lack of parental attention.

The family, especially parents do have a vital role in the psychological development of children. If the child is psychologically in a fine state, then the possibility of the child bullying is very small. Conversely, if these family factors overshadow the psychological child to do bad things, children are vulnerable to becoming cyber bullying. From this we know that parents become the first stronghold for the child to not do bullying.

The role of parents, schools, universities, and the community can help reduce / prevent the possibility of cyber bullying. This responsibility is given to parents to guide their children.

Many opinions say communication between children and adults is one of the good signals to prevent children from making mistakes when using technology (online). 
"If we can get kids to be thoughtful about making decisions about what they post online then we've done a good job as parents and educators." Jon Mattleman, Director of Needham Youth Services, Massachusetts.

As Jon Mattleman said, if parents can teach children to think again and be more careful in posting text, images or anything via online, then it should be appreciated as something good.

Thus, giving directions to the child about what is appropriate and inappropriate is very important. Not only in the real world but in cyberspace (online). This direction must certainly be balanced with concrete examples. As a parent, example is very much awaited for the child. Give an example in healthy internet is very important to open up the child's insight in behaving in cyberspace. Not just stopping there, we need to know the online behavior of children in their teens. This is very important and must be learned by parents. Then, parents also need to increase supervision on the online behavior of their teenage children.

Parents can use software to monitor the child's movements in cyberspace. Unfortunately, research in the Journal of Information Systems reveals that parents sometimes say that they do not have enough skills to be able to continue to monitor their children's online activities.

Cyberbullying is an increasingly worrisome problem. Fortunately, this issue has become a public concern and there are a number of steps that can be taken to prevent this incident.

The role of parents is to recognize the emotions and thoughts of children / adolescents, and pay attention to whether the child is depressed or acting strangely. If children want to be frank that they are being bullied in cyberspace or in school, then you are fortunate enough. The majority of teenagers and children never confess to their parents, and statistics show that if they tell someone, it is more likely to be friends or siblings. Men tell people less often when they are bullied. There may be many reasons why they behave as if it were not cyberbullying. The first step that must always be done is to identify the problem. The earlier acts of oppression are identified and monitored, the better. You may have to ask children if they are bullied. Or you can ask the teacher who is also responsible for reporting this incident at the school, where the action originated.

Depending on the age of the child or teenager, the best preventive measure that can be applied is to limit the use of technology as much as possible. There is increasing evidence that children under 7 years old should not have too much access to any technological device. The fact is that devices increase cyberbullying opportunities, and cyberspace is not a ready place for children. In addition, the long-term use of technological devices for children and adolescents has a detrimental impact on health. Because technological advances are increasing and the emergence of digital devices is increasingly diverse, no longitudinal research has been carried out to find out the consequences that result from continuous exposure to smartphones, WiFi, iPad, and other types of technology. The use of such devices must be limited on a large scale especially in children.

An alternative to limiting device use directly is to limit the sites that may be seen by children. You can do this according to your internet service provider, meaning that all devices that use your home internet must follow the rules regarding what sites are restricted. This method is similar to that applied in a company. The company has a list of sites that are permitted to be accessed and rules related to downloading certain files and applications. If you buy a smartphone for your child, there are a number of parental control applications 
that can be downloaded on the cellphone. Keepers is an application that notifies parents of suspicious or dangerous messages and also includes a tracking device to show the location of children. Actually controlling children so that they can only access certain sites is very easy to do.

\section{a. Understanding Evolutionary Implementing $\begin{array}{r}\text { the } \\ \text { System of }\end{array}$
Hinduism Education}

The evolutionary system of implementing education according to Hinduism view is very universal compared to the education system in general. This means that the cycle of the process of education in Hinduism has essentially been going on since the process of conception in the mother's womb. We can understand this through Atharvaveda's words VI.17.1 "Just as this vast earth contains all beings, so also my wife, you become pregnant and from that pregnancy a son can be born like the sun filled with light". Like in everyday life, when we plant fruit seeds in the soil, of course we must try to prepare the best seeds to be planted, in addition to always maintaining and caring for the seeds that have been planted. And spiritually, of course prayer and ritual to God must be completed as another form of business (Pudja, \& Sudharta, 2004). Furthermore, as a consequence of the role of parents, teachers and the community, they must participate optimally as educational agents, in the sense that they must understand the character of students and guide them into good character, not to harass others in any opportunity like cyber bullying (Suhardana, 2010).

\section{b. Discipline Emphasis}

The family is the main school in the education process. Basically, it is because a student spend longer time in the family environment. Especially the role of a mother who is the central model to the family is very important. Nobody exceeds a mother "Nasti guruh samo mata" means that mother is a teacher. Therefore, mother must be aware of the education importance for her children. It is because children cannot be well educated if parents do not aware about the importance of the education value.

Besides that, education in the family must be integrated with education that has been received in schools and in the community. Every agent in the family should also be responsible for the success of education in the family (Winarno, 2011). The first important phase is a good example from parents, and anyone who is older in the family will help and support the education development. Likewise, giving good attention should not only once or twice but must be continued. So parent will realize the mistakes that are often made by a child.

Enforcement of discipline character in early age is like forming something that is still young that will be easier. For example we will form a Bonsai tree, so that once a young Bonsai has been tied with wire in accordance with our wishes. So that in the future the marketing of Bonsai trees becomes more value and has an attraction. Likewise, self-discipline is an absolute necessity. Especially discipline enforcement that must implement 
far before a child reaches school. Experiences given by parents through discipline education will make children wiser in facing a problem, if later they will find a case like Bullying and Cyber Bullying.

\section{c. Intensive Communication}

Harassment usually begins in the education family. The family between siblings and older siblings there is often a small dispute, but this small dispute if not noticed will be able to be a strong foundation for children accustomed to harassing anywhere and in larger portions, including on social networks. Therefore, the role of parents must be able to immediately provoke the child to get used to complaining and communicating with parent every time a fight occurs. So that, parent must be accustomed providing solutions to neutralize disputes between relatives in the family environment.

Therefore, intensive communication between fellow family members needs to be improved. Because the gap or lack of attention from parents to one party from their children will negatively affect the education process. Envy and jealousy will be able to make a child do acts that are contrary from Hinduism teachings. Parents must always be vigilant with all the movements of the child in the fabric of love. Parents must do things that are able to make the family relationship remain as an example of good education for their adult years and hanging out in the outside environment.

\section{d. Understanding the Level of Growth}

Parents must be aware of the importance of proper education of child growth in the family during the golden age. It is because during child's growth period. Children will have different ways to understand and accept the phenomena of life as a process of education in the family. Then, in this modern era parents must also be able to meet the needs of children according to their level of understanding especially related to communication and entertainment media. So that in the process of its use does not cause violation of the rules in using the media. Parents must know the right time and place how to act to their children like how their children must be spoiled, how to give appropriate punishment and when the child is valued as an adult, and this kind of education system is one of a good discipline system.

\subsection{Prevention of Cyber Bullying through Education in Schools}

Formal education or school education is a systematic, structured, multi-level activity starting from elementary school to senior high school level and equivalent to it (Suhardana, 2010). This includes academic and general oriented study activities, specialization programs, and professional training carried out in continuous time and specific period. Formal education is a structured and tiered education consisting of primary education, secondary education and higher education. Formal education is part of national education that aims to shape Indonesian people as a whole, namely those who believe and are devoted to God Almighty, has good characters, democratic, upholding human rights, mastering science, 
technology and art, having physical health and spiritually, has a life skill that is virtuous and dignified, has a strong, independent, and creative personality, and has social and national responsibilities that are able to realize an intelligent and competitive national life in global era.

The rise of cyber bullying acts in the form of tweets, status, images and videos that threaten and intimidate students is often an issue that is ignored by the teacher on the pretext that this does not occur physically in school but only in cyberspace. In fact, the actions of cyber bullying students have the potential to be the beginning of brawls, immoral acts, intimidation, and the killing of students both physically and emotionally (Priyatna, 2005). In this time school stuff and teacher must take an active and creative role to prevent cyber bullying, but not only with strict rules and consequences but develop interesting activities that can implement an anti-cyber bullying culture since school.

Cyberbullying perpetrators actually do not use the internet to find targets, but to oppress people who they have bullied at school. According to the Warwick study, $99 \%$ of students will be bullied even if new technology does not exist, so digitalization of information only adds one percent. So, in fact digital technology itself is not the source of the problem. But, making existing problems worse. If the problem can be solved at school, then it won't happen at home. Digital platforms are just tools to reach existing targets. Statistics for teens bullied online and face to face are almost the same. According to a report by the US Center for Education Statistics (NCES) in 2017, the most common reasons for bullying reported by students are appearance $(27 \%)$, race (10\%), ethnicity (7\%), gender (7\%), disability (4\%), religion (4\%) and sexual orientation $(3 \%)$.
Another trend that continues to play alone is that those who are the target of bullying usually replace bullying more people. Women tend to report more as victims of cyberbullying. Generally cyberbullying occurs when someone looks different. The cultural context in certain schools can also affect a child being bullied or not.

Generally, there are 4 main types of bullying, namely social media, harassment, flaming, and exclusion. The suppression of social media is all forms of bullying that occur on social media platforms, such as Facebook or Twitter. Harassment is a threat, expressions of hatred or intimidation that can occur through various channels, both in groups and individuals. Flaming is a reproach and an insult to someone publicly, so that others can see, both online and offline. And exclusion is an action where individuals are ignored or not invited to social events. The victim can then be mocked by his friends without the victim's knowledge. Flaming is the most embarrassing act and can be the longest experienced by a child or teenager. But exclusion is probably the most difficult to prove and overcome. For example, a child is dropped from a list of friends or not invited to a particular event, in fact it is not a form of abuse for the child, but painful.

On the other hand, when cyberbullying is on the rise, there is a positive record of physical bullying which has decreased significantly over several years. Physical violence is a form of bullying that is far more common in previous decades and is now drastically reduced. According to the US Bureau of Justice Statistics, acts of physical violence on adolescents reached an all-time low in 2014. In addition, a study conducted by the Massachusetts Department of Primary and Secondary Education found a $22 \%$ reduction in bullying percentage in Massachusetts between 2003 and 2011. 
Difficulties in overcoming cyber bullying is because events occur most often in instant messaging services. These messages are encrypted and are private, such as Facebook Messenger, Whatsapp, Line, WeChat, and Snapchat. So there are no real notes unless you directly take your child's device, see the message, and take a screenshot. Another case with emails that are public comments so much easier to note.

According to the Centers for Disease Control, $15 \%$ of high school students are bullied in cyberspace and $20 \%$ are bullied in school environments. According to the Cyberbullying Research Center, the percentage of people who have experienced cyberbullying at some stage in their lives almost doubled from 2007 to 2016.

There are some technical limitations to doing this. These controls include:

a. Use parental controls in the video game console. Players often talk to each other and send messages on video games. Manage your child's account, limit who they can talk to and monitor the content of the game being played.

b. Find out in detail every parent's control from all social media sites, including Twitter, Facebook, and Instagram.

c. Teach your children about this control. Telling children that blocking others on social media sites, video game consoles and even phone calls is very easy to do. If your child feels bullied on the internet, suggest he block the person. Email addresses can also be blocked.

d. If someone hacked your child's account and pretended to be them in cyberspace, you can change your password or contact the relevant site and report the action. Most popular sites are very helpful when there are security problems.

\section{CONCLUSION}

Cyber bullying is all forms of violence experienced by children or adolescents and carried out by their friends in the peer age through the cyber world or the internet. Cyber bullying is an incident when a child or teenager is ridiculed, humiliated, intimidated, or humiliated by another child or teenager through internet media, digital technology or cell phone. Regarding in prevention process, there are two characteristics, namely those that understand the principles of how to use technology; This means that users must have good resources about technology so that there is an effort to avoid cyber bullying.

Then, the prevention through human spiritual moral education especially in family education because the family is central in instilling good morality in order to understand the advancement of modern technology. For example, running the evolutionary process of education in Hinduism, emphasizing discipline and there must be intensive communication, and understanding the level of children growth. So that, nothing harassment occurs against others. Likewise, prevention through education in schools such as implementing the use of social media in lessons, posting anti-cyber bullying posters, forming cyber angel movements, holding a celebration of "social media" and the cultivation of Hinduism education in good and right way.

One of the best ways to ensure protection in cyberspace for children or adolescents is with a high-quality Virtual Private Network (VPN). VPN installation is very easy to do and the cost is quite cheap. VPN is responsible for encrypting network traffic, so hackers cannot spy on children when they are online. VPNs will also hide information from ISPs so that their data is not taken and sold for commercial purposes, and also hides information from sites that try to collect data on all online activities. There are currently a variety of VPN options available for customers and all of them have configurable settings for maximum protection. Teaching children how to use VPN is one of the best things they can learn 
and implement to maintain cyber security and is a technology that will help them for years to come. VPN has been recognized by security experts as one of the best techniques in terms of privacy protection when surfing and anonymity. Good VPNs include IPVanish, Express VPN, NordVPN and many more.

\section{REFERENCES}

Furgon, I. K. (2010). Internet Asik Untuk Anak. Yogyakarta: Galangpress Group.

Saksono, G. (2008). Pendidikan yang Memerdekakan Siswa. Jogjakarta: Rumah Belajar Yabinkas.

Samba, I G. (2013). Merajut Ulang Budaya Luhur Bangsa. Bandung: Yayasan Dajan Rurung.

Suhardana, K. (2010). Tat Twam Asi, Ajaran Kesamaan Martabat Manusia. Surabaya: Paramita.

Titib, I M. (2006). Menumbuhkan Pendidikan Budhi Pekerti Pada Anak. Denpasar: Bali Post.

Pudja, G \& Sudharta, T. R. (2004). Manava Dharmasastra. Surabaya: Paramita.

Priyatna, A. (2005). Lets End Bullying. Jakarta: Alex Media Komputindo.

Winarno. (2011). Pendidikan Kewarganegaraan. Jakarta: Bumi Aksara 